\title{
Effects of two PBDE congeners on the moulting enzymes of the freshwater amphipod Gammarus pulex
}

\author{
Eric Gismondi*, Jean-Pierre Thomé \\ Laboratoire d'Ecologie Animale et d'Ecotoxicologie (LEAE), Institue de Chimie, Bât. B6C, 15 allée du 6 Août, Sart-Tilman, Université de Liège, B-4000 Liège, \\ Belgium
}

\section{A R T I C L E I N F O}

\section{Article history:}

Received 4 January 2014

Received in revised form

3 April 2014

Accepted 6 April 2014

Available online $\mathrm{xxx}$

\section{Keywords:}

Polybrominated diphenyl ether (PBDE)

Gammarus pulex

Moult

Chitobiase

Bioaccumulation

\begin{abstract}
A B S T R A C T
Polybrominated diphenyl ethers (PBDEs) are abundant in aquatic environment. However, only few studies have investigated their impacts on freshwater invertebrates. This work aimed to study the effects of BDE-47 and BDE-99 congeners on the chitobiase and chitinolytic enzymes activities of the freshwater amphipod Gammarus pulex, according to gender, PBDE concentration and time of exposure. In addition, the bioaccumulation of BDE-47 and BDE-99 were measured. Results revealed that females have bioaccumulated more PBDE than males, and BDE-99 was more accumulated than BDE-47. PBDE exposures for $96 \mathrm{~h}$ have caused chitobiase and chitinolytic enzymes inhibition. This study not only indicate the importance of taking into account various confounding factors (gender, congeners, concentration) to understand PBDE effects, but underline also disruptions of molting enzymes activities. These disturbances suggest effects on the gammarid development and reproduction, and consequently effects on the gammarid population, and on a larger scale, a dysfunction of the ecosystem.
\end{abstract}

(C) 2014 Elsevier Ltd. All rights reserved.

\section{Introduction}

Polybrominated diphenyl ethers (PBDEs) constitute a class of chemical compounds included to the composition of usual products such as plastics, textiles or electrical equipment, due to their flame retardants properties (Alaee et al., 2003). Since 2004, PBDEs are banned in Europe and listed as Priority Substances within the European Union Water Frame Work Directive (Coquery et al., 2005). Unfortunately, the release of PBDEs in ecosystems continues due to their presence in products currently in use and new products manufactured using recycled PBDE-containing material (La Guardia et al., 2006). As PBDEs are environmental persistent xenobiotics and bioaccumulated in biota (de Wit et al., 2010), the need to determine their effects on biota is important. Indeed, recent studies have underlined that PBDEs could be bioaccumulated in tissues of some aquatic organisms such as fish (Tomy et al., 2004; Isosaari et al., 2005; Lema et al., 2007), bivalves (Gustafsson et al., 1999; Parolini and Binelli, 2012) or amphipods (Tlili et al., 2012). Despite these observations and the fact that PBDEs have a widespread distribution in environment, most of the studies which have investigated their potential toxic effects, have

\footnotetext{
* Corresponding author.

E-mail address: gismondi.eric@gmail.com (E. Gismondi).
}

been conducted on mammalian models (e.g. rats, mice Darnerud et al., 2001). However, investigations of PBDEs effects on aquatic organisms are increasing, and particularly the effects of the BDE-47 and BDE-99 congeners. Indeed, Breitholtz and Wollenberger (2003) have demonstrated that the BDE-47 congener could induce a decrease of the larval development and population growth rates of the copepod Nitocra spinipes exposed for full-life cycle. In addition, Baršienè et al. (2006) have underlined the induction of nuclear injuries in the gill tissues of the blue mussel (Mytilus edulis) exposed to $5 \mu \mathrm{g} \mathrm{L}^{-1}$ of BDE-47 for three weeks. These authors have also described an increase of micronuclei frequency as well as inductions of bi-nucleated and fragmented-apoptotic cells and nuclear buds. An increase of the micronuclei proportion was also observed in the bivalve Dreissena polymorpha exposed to BDE-47 (Parolini and Binelli, 2012). PBDEs can also affect the reproduction of organisms. For example, Muirhead et al. (2006) have observed, in the fish Pimephales promelas, a reduction of sperm maturation in males ( $>50 \%)$ and an egg production stopped in females exposed for 10 days to BDE-47. In this same organism, Lema et al. (2008) have highlighted that PBDEs could be an endocrine disruptor as BDE-47 caused an increase of the thyroid hormone (TH) receptor $\alpha$ in females and a decrease of the TH receptor $\beta$ in both genders. The endocrine disruptor potential of PBDEs was also underlined by Wollenberger et al. (2005) in the copepod Acartia tonsa in which a BDE-99 
exposure induced an antagonistic effect of the ecdysteroid hormones (steroid hormones regulating development and reproduction in arthropods). More recently, Zhang et al. (2012) have demonstrated that BDE-47 could increase estrogen receptor in the scallop Chlamys farreri. In Daphnia magna neonates, Davies and Zou (2012) have shown that PBDEs disrupt the moult, which is controlled by ecdysteroid hormones.

Among freshwater species, Gammarus sp. is a suitable organism for ecotoxicological assessment of environmental pollutants at a large scale, because gammarids are present in most (if not all) rivers in Europe (Jażdżewski, 1980). Gammarids are known to be sensitive to pollutants and can easily be used in laboratory and field studies (Kunz et al., 2010). Hence, many ecotoxicological studies have been carried out using gammarids to evaluate impacts of xenobiotics (Leroy et al., 2010; Sornom et al., 2010, 2012; Gismondi et al., 2012a, 2013; Vellinger et al., 2012). However, to our knowledge, no study has been devoted to PBDEs effects on Gammarus sp., although this specie offers advantages (e.g. easy identification, widespread distribution) and plays important roles in the trophic chain (i.e. food resource for fish, amphibians and birds), but also in the organic matter recycling (i.e. leaf degradation).

In the present study, we investigated the effects of PBDEs on the physiological responses of the freshwater amphipod Gammarus pulex. According to the field study of Tlili et al. (2012), we have chosen to work particularly with the two major congeners bioaccumulated in Gammarus pulex, i.e. 2,2',4,4'-tetrabromodiphenyl ether (BDE-47) and 2,2',4,4',5-penta-bromodiphenyl ether (BDE-99). In a first experiment, we studied the bioaccumulation of each PBDE in Gammarus pulex whole body. Then, as PBDEs are suspected to be endocrine disruptors (Wollenberger et al., 2005; Zhang et al., 2012) and that crustacean moult is hormonally controlled (Hyne, 2011), we investigated the effects of BDE-47 and BDE-99 on the activity of the three chitinolytic enzymes: $\beta$-N-acetylglucosaminidase, chitobiosidase and endochitinase. This measure ensures to assess the moulting disruption called the invisible endocrine disruption since the disruption of crustacean moulting is not readily seen in the field (Zou, 2005). In parallel, we measured the chitobioase activity (enzyme released into the medium during the moult) in the water of exposure, according to the time of exposure. To ensure a comprehensive view of the toxic effects of a PBDEs exposure on a population of Gammarid, all measurements were carried out in males and females separately.

\section{Material and methods}

\subsection{Sample collection}

Male and female Gammarus pulex were collected using a pont net in the BlancGravier brook (50 $34^{\prime} 60^{\prime \prime} \mathrm{N}$ and $5^{\circ} 34^{\prime} 60^{\prime \prime} \mathrm{E}$, Colonster, Belgium) in autumn 2012. This site was chosen as a reference site due to its good physico-chemical quality (see Leroy et al., 2010 for details). Individuals were sorted out on the spot by observing gnathopods (smaller in females than in males) and transferred to the laboratory $(\sim 10 \mathrm{~km})$ where they were maintained at $15^{\circ} \mathrm{C}$ in large aerated aquaria and fed ad libitum with alder leaves, until PBDEs exposures.

\subsection{Experimental solutions}

Solutions of BDE-47 and BDE-99 were purchased from Sigma-Aldrich Co. BDE47 and BDE-99 stock solutions of $1000 \mu \mathrm{g} \mathrm{L}^{-1}$, diluted in acetone, were store in amber glass vials at $-20^{\circ} \mathrm{C}$. The experimental concentrations of each PBDE were obtained by diluting the respective stock solution in mineral water (Volvic, France). To give a marked ecological relevance to our research, the exposure concentrations of BDE were chosen according to BDE concentrations measured in invertebrates collected in the field in a preliminary study (Thomé and Leroy, 2012). In addition, to compare the toxicity of the two studied congeners, we decided to test the same concentrations for each BDE, i.e. $0.1 \mu \mathrm{g} \mathrm{L}^{-1}$ and $1 \mu \mathrm{g} \mathrm{L}^{-1}$ (Table 1). Acetone controls were carried out in parallel to Volvic controls. As no significant differences were observed between these two controls, only the Volvic controls were included in results to avoid overloading results.
Table 1

Nominal and measured concentrations of BDE-47 and BDE-99 ( $\left.\mu \mathrm{g} . \mathrm{L}^{-1}\right)$ in water of exposure.

\begin{tabular}{|c|c|c|c|c|c|}
\hline & Control & BDE-47 & & BDE-99 & \\
\hline $\begin{array}{l}\text { Nominal } \\
\text { concentration } \\
\left(\mu \mathrm{g} \mathrm{L}^{-1}\right)\end{array}$ & 0 & 0.1 & 1 & 0.1 & 1 \\
\hline $\begin{array}{l}\text { Measured } \\
\text { concentration } \\
\left(\mu \mathrm{g} \mathrm{L}^{-1}\right)\end{array}$ & 0 & $0.17 \pm 0.015$ & $0.77 \pm 0.036$ & $0.12 \pm 0.010$ & $1.3 \pm 0.006$ \\
\hline
\end{tabular}

\subsection{Bioaccumulation assays}

\subsubsection{Exposure conditions}

Contaminations were performed in glass Petri dishes $(100 \mathrm{~mm}$ diameter and $20 \mathrm{~mm}$ high), previously saturated with the corresponding tested solutions for 3 days, to avoid BDE adsorption during the gammarids exposure. For each tested condition, three replicates of 5 G. pulex males or females were exposed at $15^{\circ} \mathrm{C}$ for $96 \mathrm{~h}$ with a photoperiod of $16 \mathrm{~h}$ light and $8 \mathrm{~h}$ darkness. Experimental media renewed every day in order to guarantee a constant concentration of BDE over the exposure. During exposure, gammarids were not fed. At the end of the experiment, 3 pools of 5 G. pulex males or females were constituted for each condition, frozen in liquid nitrogen and stored at $-80{ }^{\circ} \mathrm{C}$ before bioaccumulation analyses.

\subsubsection{BDE concentrations in G. pulex}

Each pool of G. pulex was lyophilized overnight using a Cryotec Lyophiliser. Then pressurized liquid extraction (PLE) was performed on freeze-dried samples using an Accelerated Solvent Extractor (ASE ${ }^{\mathrm{TM}}$ 200) (Dionex, Sunnyvale, USA) with hexane Pestinorm ${ }^{\circledR}$ : dichloromethane Pestinorm ${ }^{\circledR}(90: 10$, v:v) as solvent. Fat extracts were dried under a gentle stream of nitrogen at $37{ }^{\circ} \mathrm{C}$ (TurboVap). Samples were resuspended in $3 \mathrm{~mL}$ of hexane Pestinorm ${ }^{\circledR}$ and doped with $50 \mu \mathrm{L}$ of PCB 112 at $100 \mathrm{pg} \mu \mathrm{L}^{-1}$ as a surrogate, to controlled clean-up processes.

For the acid clean-up, samples were mixed with $2 \mathrm{~mL}$ of sulphuric acid $98 \%$ for $2 \mathrm{~min}$ and centrifuged for $3 \mathrm{~min}$ at $3000 \mathrm{rpm}$. Supernatants were transferred in new test tubes and the remaining samples were washed with $3 \mathrm{~mL}$ of hexane Pestinorm ${ }^{\circledR}$ and centrifuged for $3 \mathrm{~min}$ at $3000 \mathrm{rpm}$. The second supernatants were pooled with the first, and concentrated to $1 \mathrm{~mL}$ under a gentle stream of nitrogen, prior to the second clean-up on Florisil cartridges.

The Florisil clean-up was performed using supelclean Envi-Florisil SPE $6 \mathrm{~mL}$ column (Supelco, Bellefonte, USA). The $1 \mathrm{~mL}$ supernatants from the acid clean-up were eluted on the Florisil cartridges, which were then washed with $2 \mathrm{~mL}$ of hexane Pestinorm ${ }^{\circledR}$, to ensure full recovery of the sample. The obtained samples were dried under a gentle stream of nitrogen and resuspended in $50 \mu \mathrm{L}$ of hexane

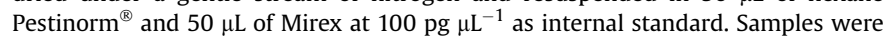
analysed in capillary gas chromatography with an electron capture detector (GCECD) using a Thermoquest Trace GC 2000 (Milan, Italy).

Commercial solutions of BDE-47 and BDE-99 were used for the standard curve. PBDE concentrations in G. pulex were expressed in $\mu \mathrm{g} \mathrm{g}^{-1}$ dry weight (dw).

\subsection{Chitobiase activity and chitinolytic enzymes activities}

\subsubsection{Exposure conditions}

BDE contamination was performed with the same BDE concentrations and photoperiod conditions as described above (see Bioaccumulation assays). The experiment was conducted using five replicates of one G. pulex male or female in similar intermoult $C$ stage. Water of exposure were changed daily and $4 \mathrm{~mL}$ of each replicate of the same condition were pooled in a $20 \mathrm{~mL}$-amber glass vial. Chitobiase activity measurements were carried out on the day water collection. At the end of the experiment, gammarids were frozen individually in liquid nitrogen and stored at $-80{ }^{\circ} \mathrm{C}$ awaiting chitinolytic enzymes assays.

\subsubsection{Chitobiase activity in water of exposure}

The chitobiase activity assessment was performed according to the method developed by Hanson and Lagadic (2005) in 96-well microplate. The assay is based on the degradation of the 4-methylumbelliferyl N-acetyl- $\beta$-D-glucosaminide (MUFNAG) in 4-methylumbelliferyl acetate (NAG). Before proceeding to the assay, water of exposure was filtered on $0.22 \mu \mathrm{m}$ membrane to eliminate bacteria that could also display chitobiase activity. Each sample was measured in duplicate; the average was calculated and used in all subsequent analyses. Chitobiase activity was expressed in $\mu \mathrm{mol} . \mathrm{hr}^{-1}$.

\subsubsection{Chitinolytic enzymes activities in G. pulex}

Chitinolytic enzymes activities were assessed by using the "Chitinase Assay Kit, Fluorescence" from Sigma-Aldrich Co.

Each G. pulex male or female was homogenized with a manual Eppendorf pestle in microtubes. The homogenization buffer was adjusted to the G. pulex wet weight (ratio 10:1, v:w) and was composed to CelLytic MT reagent (Sigma-Aldrich Co.) 
supplemented with Proteinase Inhibitor Cocktail $(1 \mu \mathrm{L}$ of Proteinase Inhibitor Cocktail for $100 \mu \mathrm{L}$ of CelLytic MT reagent; Sigma-Aldrich Co.). Samples were centrifuged for $10 \mathrm{~min}$ at $15000 \times \mathrm{g}, 4^{\circ} \mathrm{C}$ and the resulting supernatants were 10 fold diluted in homogenization buffer before being used for the assay.

As three different substrates were necessary to measure chitinolytic enzymes activities (i.e. 4-methylumbelliferyl N,N'-diacetyl- $\beta$-D-chitobioside, 4methylumbelliferyl $\mathrm{N}$-acetyl- $\beta$-D-glucosaminide and 4-methylumbelliferyl $\beta$-D$\mathrm{N}, \mathrm{N}^{\prime}, \mathrm{N}^{\prime \prime}$-triacetylchitotriose used to assess chitobiosidase, $\beta$-N-acetylglucosaminidase and endochitinase activity, respectively), we used one 96-well microplate per substrate. Briefly, each 96-well microplate contained a blank (i.e. appropriated substrate solution), a sample blank (i.e. $95 \mu \mathrm{L}$ of assay buffer and $5 \mu \mathrm{L}$ of diluted sample), a positive control (i.e. $95 \mu \mathrm{L}$ of appropriated substrate solution and $5 \mu \mathrm{L}$ of control chitinase solution) and a five point 4-methylumbelliferone (MUF) standard curve. Each sample was measured in triplicate and the average was calculated and used in all subsequent analyses. Chitinolytic enzymes activities were expressed in $\mu \mathrm{g} \min ^{-1} \mathrm{mg}$ protein ${ }^{-1}$.

Protein concentrations were measured in 96-well microplate in the diluted supernatants by using the "Protein Quantification Kit-Rapid" from Sigma-Aldrich Co. based on the Bradford method (Bradford, 1976).

\subsection{Statistical analysis}

All data met normality and homogeneity of variance assumptions (Shapiro and Bartlett tests, $p>0.05$ ). Our data were analyzed by using a univariate analysis of variance (ANOVA) to test the effect of PBDE congeners and concentration, gammarid gender, time of exposure and their interactions. Then, TukeyHSD post-hoc tests were used to describe significant differences. All tests were performed with a 5\% type-I error risk, using R 2.9.0 Software.

\section{Results}

\subsection{BDE-47 and BDE-99 accumulation}

After $96 \mathrm{~h}$ of exposure, there was a dose-dependent accumulation of PBDE in G. pulex, whatever the gender and the PBDE congeners (Fig. 1). Indeed, the BDE-47 concentrations in G. pulex were 7 times higher in individuals exposed to $1 \mu \mathrm{g} \mathrm{L}^{-1}$ than in individuals exposed to $0.1 \mu \mathrm{g} \mathrm{L}^{-1}$. Similarly, BDE-99 concentrations in G. pulex were an average 11-fold higher in gammarids exposed to $1 \mu \mathrm{g} \mathrm{L}^{-1}$ than in gammarids exposed to $0.1 \mu \mathrm{g} \mathrm{\textrm {L } ^ { - 1 }}$. No differences were observed between BDE concentrations in males and females exposed to $0.1 \mu \mathrm{g} \mathrm{L}^{-1}$, whatever the BDE congener. However, at the highest exposure concentration, the BDE concentrations in G. pulex were 1.5-fold higher in females than in males, whatever the BDE congener. Results revealed that, when exposed to the highest concentration, BDE-99 concentrations were 3.5 and 2.7 times higher than BDE-47 in males and females, respectively.

\subsection{Chitobiase activity}

Chitobiase activity was influenced by BDE congener, G. pulex gender and the time of exposure (Table 2, Fig. 2). Indeed, whatever the gender, chitobiase activity was different depending on whether gammarids had been exposed to BDE-47 or BDE-99. When exposed

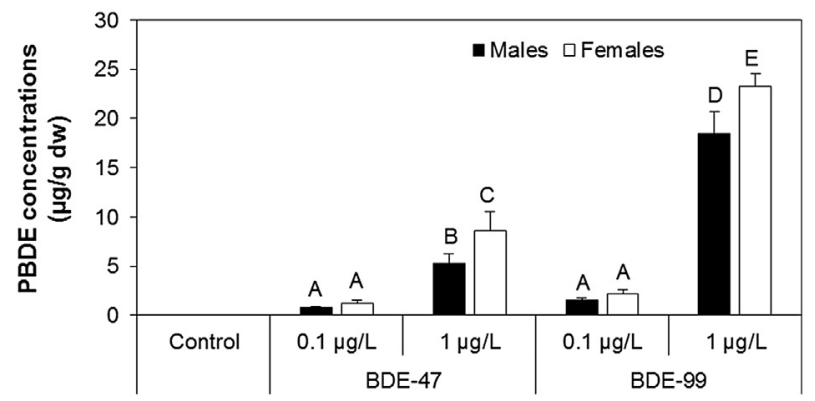

Fig. 1. Bioaccumulation of BDE-47 and BDE-99 in Gammarus pulex males and females exposed at two concentrations, $0.1 \mu \mathrm{g} \mathrm{L}^{-1}$ and $1 \mu \mathrm{g} \mathrm{L} \mathrm{L}^{-1}$ for $96 \mathrm{~h}$ (mean \pm s.d., $N=3$ ). Different letters above the bars indicate significantly different values (Tukey's HSD test, $p$-values $<0.05$ )
Table 2

Univariate analyses of variance (ANOVA) investigating variations in chitobiase activity in water of exposure according to PBDE concentrations and congeners (PBDE), gender and time of exposure.

\begin{tabular}{lcrrl}
\hline Source of variation & Sum of square & d.f & \multicolumn{1}{l}{$F$} & $p$-Values \\
\hline PBDE & 1274.4 & 4 & 188.65 & $<0.001$ \\
Gender & 214.2 & 1 & 126.81 & $<0.001$ \\
Time & 2137.6 & 3 & 421.91 & $<0.001$ \\
PBDE $\times$ Gender & 153.6 & 4 & 22.75 & $<0.001$ \\
PBDE $\times$ Time & 3187.7 & 12 & 157.29 & $<0.001$ \\
Gender $\times$ Time & 501.0 & 3 & 98.88 & $<0.001$ \\
PBDE $\times$ Gender $\times$ Time & 819.1 & 12 & 40.42 & $<0.001$ \\
Residuals & 608.0 & 360 & & \\
\hline
\end{tabular}

to BDE-99, the major effect was observed in gammarids exposed for $48 \mathrm{~h}$ compared to respective controls. In females exposed for $48 \mathrm{~h}$, whatever the BDE-99 concentration, the chitobiase activity was inhibited as compared to $48 \mathrm{~h}$-females controls. In males exposed for $48 \mathrm{~h}$ to BDE-99 at $0.1 \mu \mathrm{g} \mathrm{L}^{-1}$, the chitobiase activity was inhibited, while no effect was observed after a 48 h-exposure to BDE-99 at $1 \mu \mathrm{g} \mathrm{L}^{-1}$ as compared to $48 \mathrm{~h}$-males controls.

When exposed to BDE-47 at $0.1 \mu \mathrm{g} \mathrm{L}^{-1}$, only $G$. pulex males exposed for $48 \mathrm{~h}$ displayed a 1.5 -fold increase of the chitobiase activity as compared to control. No differences were observed at other times of exposure in comparison to respective controls. After 24 and 48 h of exposure to BDE-47 at $1 \mu \mathrm{g} \mathrm{L}{ }^{-1}$, chitobiase activity was 3.5- and 1.5-fold higher than respective controls while after $96 \mathrm{~h}$ of exposure, the chitobiase activity was 3.3-fold lower than respective control. In females exposed to BDE-47 at $0.1 \mu \mathrm{g} \mathrm{L}^{-1}$, chitobiase activity was 3.8 -fold lower after $48 \mathrm{~h}$ of exposure and 1.5 -fold higher after $96 \mathrm{~h}$ than respective controls. On the contrary, when females were exposed to BDE-47 at $1 \mu \mathrm{g} \mathrm{L}^{-1}$, the chitobiase activity was 9-fold higher after $24 \mathrm{~h}$ of exposure, and was 1.6 to about 4.5 times lower after $48 \mathrm{~h}, 72 \mathrm{~h}$ and $96 \mathrm{~h}$ of exposure, as compared to respective controls.

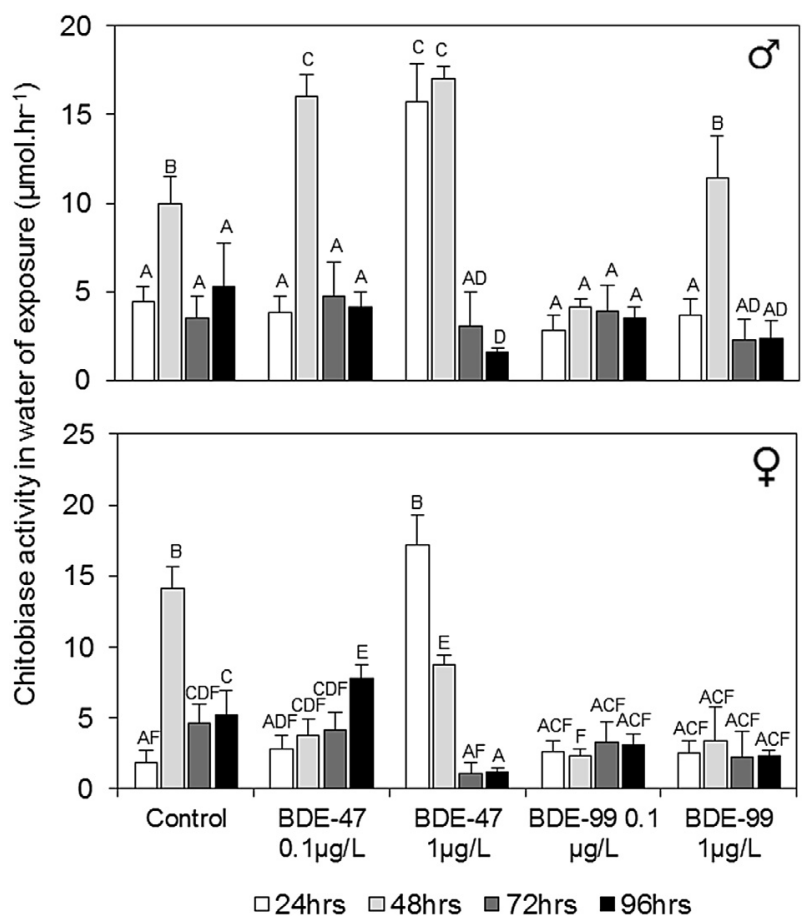

Fig. 2. Chitobiase activity in media from $G$. pulex males ( $\left.\delta^{\star}\right)$ and females ( $($ ) exposed to BDE-47 and BDE-99 at $0.1 \mu \mathrm{g} \mathrm{L}^{-1}$ and $1 \mu \mathrm{g} \mathrm{L}^{-1}$ (mean \pm s.d., $N=5$ ). Different letters above the bars indicate significantly different values (Tukey's HSD test, $p$ values $<0.05$ ) 


\subsection{Chitinolytic enzymes activities}

All the three chitinolytic enzymes were influenced by the BDE congener and concentrations, but only the $\beta$-N-acetylglucosaminidase and endochitinase activities were also influenced by the gammarid gender (Table 3, Figs. 3 and 4). However, only the $\beta-\mathrm{N}$ acetylglucosaminidase activity was impacted by the interaction between these three factors. Whatever the gender, the total activity of enzymes involved in the chitin degradation (i.e. the sum of the three enzyme activities) is mainly represented by the activity of the $\beta$-N-acetylglucosaminidase.

In G. pulex males exposed to BDE-47 (Fig. 3), chitinolytic enzymes activities were decreased whatever the concentration compared to respective controls. At $0.1 \mu \mathrm{g} \mathrm{L}^{-1}$, the activities of the $\beta$-N-acetylglucosaminidase, chitobiosidase and endochitinase enzymes were $1.4,1.9$ and 1.7 -fold lower than control, respectively. At $1 \mu \mathrm{g} \mathrm{L}^{-1}$, the three enzymes activities were 2.2, 1.8 and 1.5 -fold lower than control. In addition, comparing the enzymes activities between the low and high BDE-47 concentration, only the $\beta-\mathrm{N}$ acetylglucosaminidase activity was lower in males exposed to BDE47 at $1 \mu \mathrm{g} \mathrm{L}^{-1}$ than in males exposed to BDE-47 at $0.1 \mu \mathrm{g} \mathrm{L}{ }^{-1}$ (i.e. 1.5fold lower). In contrast, no significant differences were observed when G. pulex males were exposed to BDE-99 at $0.1 \mu \mathrm{g} \mathrm{L}^{-1}$. However, when exposed at $1 \mu \mathrm{g} \mathrm{L}^{-1}$, the activities of $\beta$-N-acetylglucosaminidase and chitobiosidase were 2.1 and 1.5 -fold lower than control, respectively.

In females, chitinolytic enzymes activities of females were weakly or not impacted by the BDE exposure (Fig. 4). Indeed, when exposed to BDE-47 at $0.1 \mu \mathrm{g} \mathrm{L}{ }^{-1}$, only the $\beta$-N-acetylglucosaminidase activity was 1.2 -fold higher than control, while in females exposed to BDE-47 at $1 \mu \mathrm{g} \mathrm{L}^{-1}$, only the endochitinase activity was 1.5-fold higher than control. After the BDE-99 exposure, whatever the concentration, no significant differences were observed in the $\beta$-N-acetylglucosaminidase activity, while the endochitinase activity was 1.7 -fold higher than control. Chitobiosidase activity was significantly 1.4-fold higher and tended to be higher than control at $0.1 \mu \mathrm{g} \mathrm{L}^{-1}$ and $1 \mu \mathrm{g} \mathrm{L}^{-1}$, respectively.

\section{Discussion}

\subsection{Dose- and congener-dependent impact of PBDEs}

Results of PBDEs bioaccumulation in G. pulex have highlighted that accumulation depends on the PBDE congener and concentration. Indeed, although at the lowest concentration of exposure and whatever the gender, no differences were observed between BDE47 and BDE-99 bioaccumulated concentrations in G. pulex, at the highest concentration of exposure, BDE-99 was more accumulated in both genders than BDE-47. To our knowledge, no study was devoted to compare the bioaccumulation of BDE-47 and BDE-99 in freshwater invertebrates in laboratory conditions. However, this result is surprising as several field studies have highlight a greater bioaccumulation of BDE-47 as compared to BDE-99 in various aquatic species as flounder, blue mussel, aquatic oligochaete or amphipods (Christensen et al., 2002; Wu et al., 2008; Ciparis and Hale, 2009; Tlili et al., 2012; Waszak et al., 2012). In our study case, the higher BDE-99 accumulation in G. pulex as compared to BDE-47 accumulation could be explained by the fact that the BDE99 concentration in the water of exposure was higher than the BDE47 one, especially at $1 \mu \mathrm{g} \mathrm{L}{ }^{-1}$ (see Table 1 ). It could be interesting to renew this bioaccumulation experiment over a range of BDE concentrations in order to confirm this result.

Measurements of chitobiase activity in the water of exposure revealed also that PBDEs effects are congener- and concentrationdependent. Indeed, whatever the gender, BDE-99 induces only few alterations of the chitobiase activity, while BDE-47 impacts the activity of this enzyme in most of the exposure conditions. No studies were found in the literature on the effect of PBDE on chitobiase activity. However, our results are consistent with those of Mhadhbi et al. (2012) who have demonstrated, in embryos and larvae of turbot Psetta maxima, that the toxic potency of BDE-47 was higher than the toxic potency of BDE-99. These authors have shown that $\mathrm{LC}_{50}$ for embryos and larvae were 27.35 and $14.13 \mu \mathrm{g} \mathrm{L}^{-1}$ for BDE-47, and 38.28 and $29.64 \mu \mathrm{g} \mathrm{L}^{-1}$ for BDE-99, respectively. Similarly, Breitholtz and Wollenberger (2003), studying the larval

Table 3

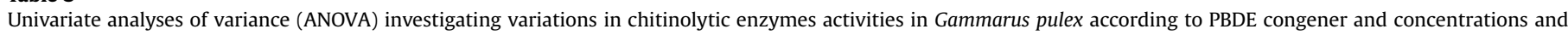
gammarid gender ( $p$-values in bold indicate significant effects of the considered parameter).

\begin{tabular}{|c|c|c|c|c|c|}
\hline Parameters & Source of variation & Sum of square & d.f & $F$ & $p$-Values \\
\hline \multirow[t]{8}{*}{$\beta$-N-acetylglucosaminidase } & Concentration & 43.99 & 2 & 186.5 & $<0.001$ \\
\hline & Congener & 0.57 & 1 & 4.89 & 0.032 \\
\hline & Gender & 5.07 & 1 & 42.98 & $<0.001$ \\
\hline & Concentration $\times$ Congener & 0.66 & 2 & 2.82 & 0.069 \\
\hline & Concentration $\times$ Gender & 27.13 & 2 & 115.02 & $<0.001$ \\
\hline & Congener $\times$ Gender & 3.04 & 1 & 25.75 & $<0.001$ \\
\hline & Concentration $\times$ Congener $\times$ Gender & 5.37 & 2 & 22.79 & $<0.001$ \\
\hline & Residuals & 5.66 & 48 & & \\
\hline \multirow[t]{8}{*}{ Chitobiosidase } & Concentration & 0.36 & 2 & 13.22 & $<0.001$ \\
\hline & Congener & 0.71 & 1 & 50.84 & $<0.001$ \\
\hline & Gender & 0.01 & 1 & 0.99 & 0.324 \\
\hline & Concentration $\times$ Congener & 0.47 & 2 & 17.02 & $<0.001$ \\
\hline & Concentration $\times$ Gender & 0.52 & 2 & 18.79 & $<0.001$ \\
\hline & Congener $\times$ Gender & 0.001 & 1 & 0.10 & 0.752 \\
\hline & Concentration $\times$ Congener $\times$ Gender & 0.04 & 2 & 1.39 & 0.259 \\
\hline & Residuals & 0.67 & 48 & & \\
\hline \multirow[t]{8}{*}{ Endochitinase } & Concentration & 0.23 & 2 & 5.94 & 0.005 \\
\hline & Congener & 0.68 & 1 & 34.50 & $<0.001$ \\
\hline & Gender & 0.66 & 1 & 33.85 & $<0.001$ \\
\hline & Concentration $\times$ Congener & 0.53 & 2 & 13.59 & $<0.001$ \\
\hline & Concentration $\times$ Gender & 0.93 & 2 & 23.83 & $<0.001$ \\
\hline & Congener $\times$ Gender & 0.01 & 1 & 0.64 & 0.426 \\
\hline & Concentration $\times$ Congener $\times$ Gender & 0.006 & 2 & 0.16 & 0.849 \\
\hline & Residuals & 0.94 & 48 & & \\
\hline
\end{tabular}



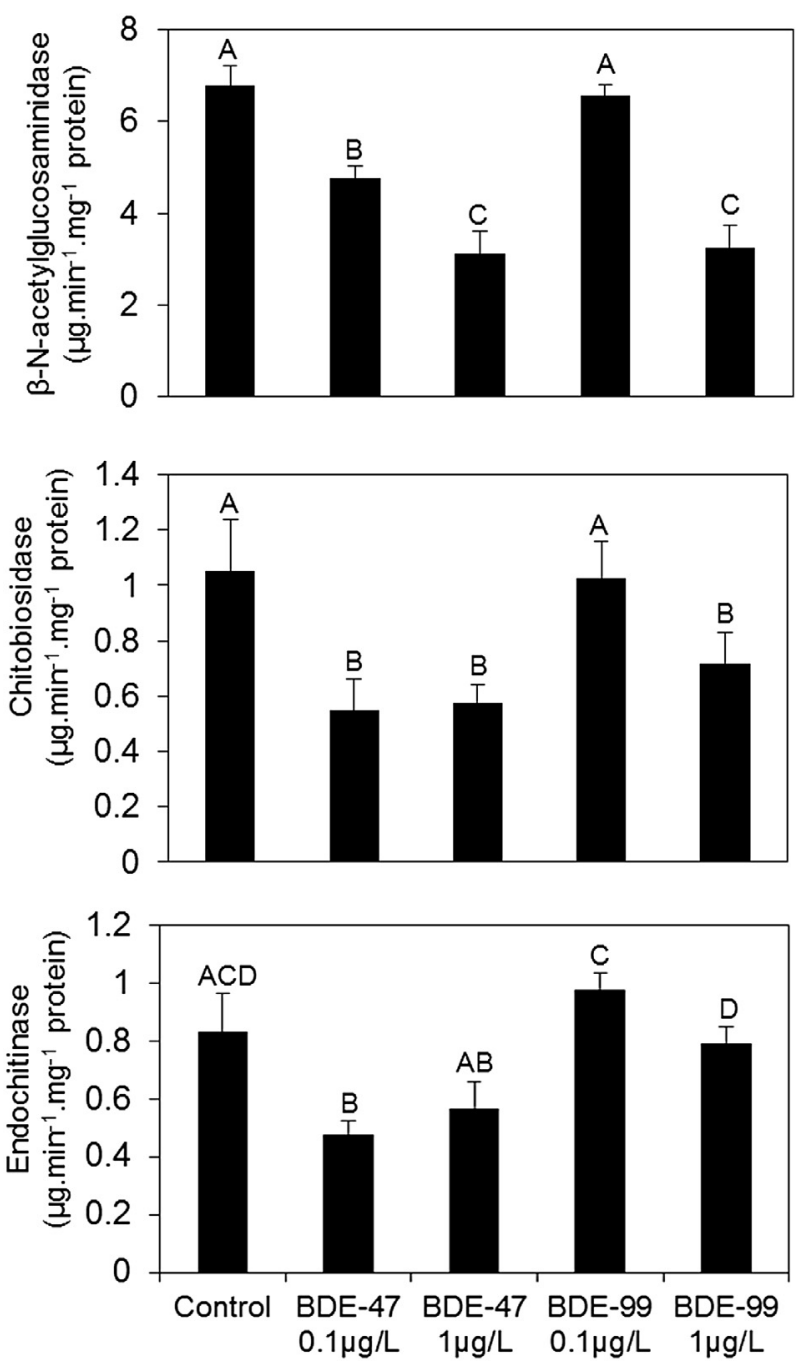

Fig. 3. Activities of the three chitinolytic enzymes of G. pulex males exposed for $96 \mathrm{~h}$ to BDE-47 and BDE-99 at $0.1 \mu \mathrm{g} \mathrm{L}{ }^{-1}$ and $1 \mu \mathrm{g} \mathrm{L}^{-1}$ (mean \pm s.d., $N=5$ ). Different letters above the bars indicate significantly different values (Tukey's HSD test, $p$ values $<0.05$ ).

development inhibition of the copepod Nitocra spinipes, have observed that the Lowest Observed Effect Concentration (LOEC) of BDE-47 was lower than the LOEC of BDE-99 (i.e. 13 and $30 \mu \mathrm{g} \mathrm{L}^{-1}$, respectively). Results of these studies as well as our results are in line with the general hypothesis which is based on the fact that the higher-numbered brominated congeners are less toxic than lowernumbered ones. The weak effect we have observed in gammarids exposed to BDE-99 could be explained by the possible biotransformation of the BDE-99 congener in BDE-47 by a debromination process, as shown by Noyes et al. (2010), and not to the presence of BDE-99 itself. This hypothesis is supported by the fact that we have measured low concentrations of BDE-47 congener in G. pulex males and females exposed to BDE-99 at $1 \mu \mathrm{g} \mathrm{L}^{-1}$ (i.e. $1616.1 \pm 82.8$ and $1286 \pm 73 \mu \mathrm{g} \mathrm{g}^{-1} \mathrm{dw}$, respectively).

Another factor that could play a role in BDE impact on chitobiase activity is the congener configuration as it has been observed by Zou and Fingerman (1999a, 1999b) with 4-octylphenol and 4-tertoctylphenol in the crab Uca pugilator. Indeed, authors have shown that the first molecule inhibited the hepatopancreas chitobiase activity but not the epidermis one, whereas the opposite effect was observed for the second molecule.

\subsection{PBDEs toxicity and gammarid gender}

Except the chitobiosidase activity, all results revealed that BDE-47 and BDE-99 impacts in G. pulex were gender-dependent. The accumulation of these two congeners in G. pulex is not surprising due to the fact that Tlili et al. (2012) have previously demonstrated, in a field study, a PBDEs bioaccumulation in G. pulex. However, our results go further, since we have demonstrated a higher PBDE accumulation in females compared to males. This observation could be explained by the fact that PBDEs are highly lipophilic compounds $\left(\mathrm{K}_{\mathrm{ow}}\right.$ ranges from 6.5 to 10; European Union (EU), 2001) and that Gammarid females have higher lipids content than males (Gismondi et al., 2012b). This hypothesis is supported by Viganò et al. (2009) who have shown that the accumulation of lower PBDEs is directly related to the lipid content of invertebrates. The higher concentrations of PBDE in females could induce a higher toxic impact in G. pulex females than in males. However, in our study, it seems difficult to confirm this hypothesis since PBDE exposure did not have the same effect on the chitobiase activity in females and males, especially when exposed to the BDE-47 congener. Indeed, when gammarids were exposed for $48 \mathrm{~h}$ to BDE-47, the chitobiase activity was inhibited in females while an increase was observed in males. At this point, we cannot determine which of these effects has a more negative impact than the other; although both
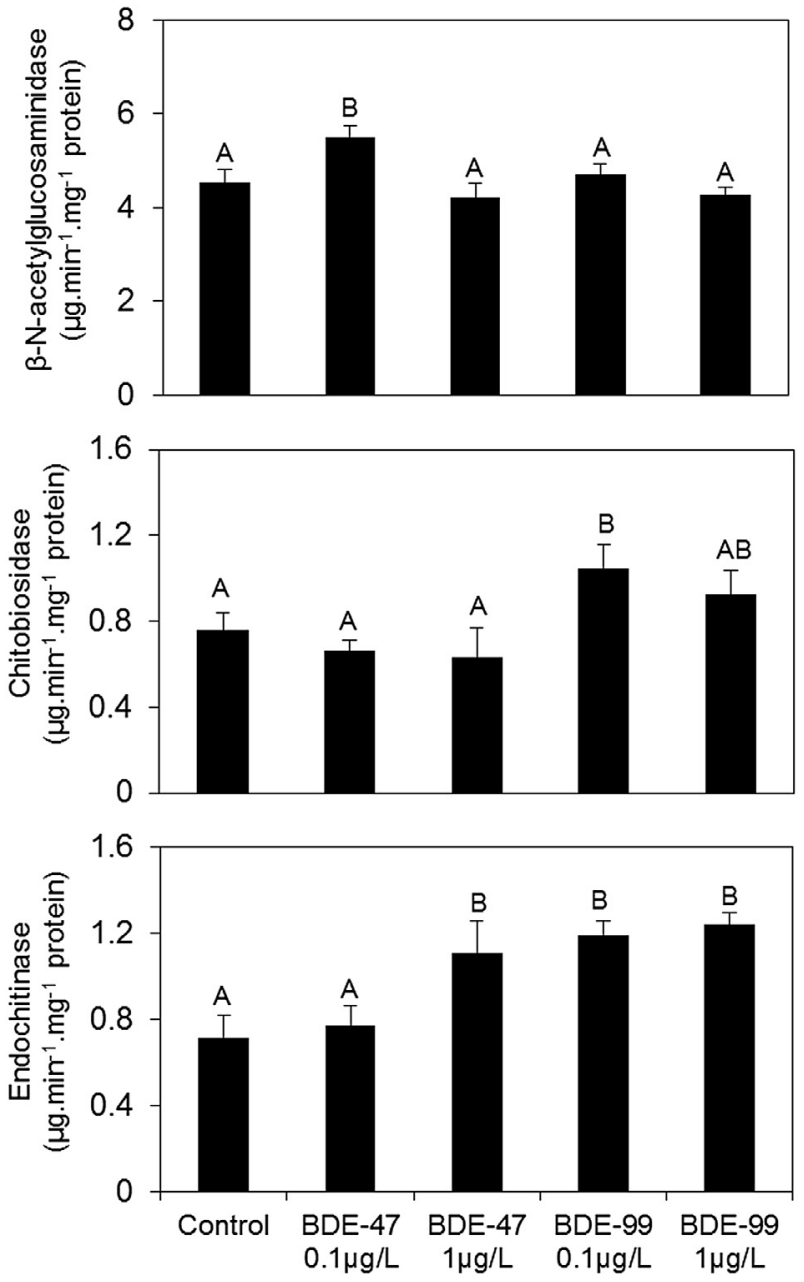

Fig. 4. Activities of the three chitinolytic enzymes of $G$. pulex females exposed for $96 \mathrm{~h}$ to BDE-47 and BDE-99 at $0.1 \mu \mathrm{g} \mathrm{L}^{-1}$ and $1 \mu \mathrm{g} \mathrm{L} \mathrm{L}^{-1}$ (mean \pm s.d., $N=5$ ). Different letters above the bars indicate significantly different values (Tukey's HSD test, $p$ values $<0.05$ ). 
could have effect on the gammarid moult cycle and thus, on gammarid reproduction and population (see section below).

Results of the activities of chitinolytic enzymes measured in organism after $96 \mathrm{~h}$ of exposure emphasize the fact that PBDEs effects are gender-dependent. Indeed, after BDE-47 exposure, we have observed an inhibition of the three chitinolytic enzymes in males, while there is overall a slight increase in females. Although chitobiosidase and endochitinase enzymes were not studied in aquatic invertebrates to our knowledge, the inhibition of the $\beta-\mathrm{N}$ acetylglucosaminidase activity by xenobiotics was already observed, especially with pollutant having similar properties than PBDEs. In fact, Zou and Fingerman (1999a) have shown that the $\beta$ $\mathrm{N}$-acetylglucosaminidase was inhibited in the epidermis and hepatopancreas of the crab Uca pugilator exposed for 3 and 7 days to PCB-29 congener. Our results confirm the fact that PBDEs disrupt the degradation of the chitin and thus, the moult cycle of gammarids, and that this disturbance is different in males and females. Therefore, it clearly appears that a PBDEs pollution could affect the gammarid population and thus, at long, the ecosystem functioning.

\subsection{Gammarid population consequences}

The increase or inhibition of the chitobiase activity observed in G. pulex suggests an increase or a decrease of the rate of chitobiase released by gammarids into the water and thus, modifications of the moult cycle. This result is in line with the recent study of Davies and Zou (2012) who have reported that PBDE exposure disrupt the moult of Daphnia magna neonates. Others studies which investigated the effect of xenobiotics on the chitobiase activity have shown similar results. For example, Richards et al. (2008) have demonstrated that an 24 h-exposure to fluoxetine caused the increase of the chitobiase activity in Daphnia magna and authors have suggested that this effect could accelerate the moult. An acceleration of the moult cycle has also been observed in other ecotoxicological studies, as in the crab Uca pugilator exposed to $p-p^{\prime}$-DDT (Weis and Mantel, 1976) or in Homarus americanus exposed to emamectine benzoate (Waddy et al., 2002). In this last study, the authors have explained their results by the fact that the xenobiotic could inhibit the release of the moult-inhibition hormone (MIH), hormone which prevents the release of the molting hormone, i.e. hydroxyecdysone hormone (20-HE). Indeed, a MIH inhibition could cause an increase of the release of 20-HE and therefore, an increase of the activity of chitinolytic enzymes. However, it seems unlikely that this mechanism is involved in our study, due to the fact that our results have not shown a continuous increase of chitobiase activity during exposure, but only an increased after $24 \mathrm{~h}$ or $48 \mathrm{~h}$, then an inhibition or a return to a similar activity than controls. Here, the principal hypothesis which could explain an increase of the chitobiase activity after $24 \mathrm{~h}$ of exposure would be an interaction between PBDEs and ecdysteroid hormone receptors, suggesting that BDE-47 could have ecdysteroid agonistic activity. However, the inhibition effect observed after $72 \mathrm{~h}$ of exposure suggests that BDE-47 congener, as well as BDE-99, could have ecdysteroid antagonistic activity, at long. These observations are in accordance with Wollenberger et al. (2005), who have demonstrated ecdysteroid antagonistic activity of BDE-99 in the copepod Acartia tonsa exposed for 5days. In addition, the paradoxical effect of BDE-47 observed at $24 \mathrm{~h}$ and $72 \mathrm{~h}$ are in line with results of Richards et al. (2008) who have shown an activation of the chitobiase activity of D. magna exposed for $24 \mathrm{~h}$ to fluoxetine, but an inhibition of this same enzyme activity after $72 \mathrm{~h}$ of exposure. These results underscore the importance of the response time in the assessment of the PBDEs effects.

The potential endocrine disruption of PBDEs in individual G. pulex could have serious consequences on the gammarid population.
Indeed, knowing that the gammarid reproduction is linked to moult cycle (Sutcliffe, 1992), changes in the moult cycle may cause disturbances in gammarids reproduction. First, due to the fact that new juveniles (brood in females marsupium) are released in environment after the moult of the females (Sutcliffe, 1992), we can hypothesis that an inhibition of the moult process in ovigerous females could lead to a late release of juveniles compared to their development. The second hypothesis is that PBDEs exposure could directly impact the juvenile's development in marsupium since this embryo development uses vitellus which is produced from lipids. Hence, a transfer of pollutant from females to eggs could happen, and PBDEs compounds ended up in eggs. This hypothesis is supported by Breitholtz and Wollenberger (2003) who have demonstrated that PBDEs reduced the larval development rate as well as the population growth rate of the copepod Nitocra spinipes. However, although our results suggest negative impacts of PBDEs exposures on juvenile's development and gammarid population, further works are required to investigate long-term effects of these pollutants.

\section{Conclusions}

To our knowledge, this study was the first to highlight physiological effects of PBDE exposure on chitobiase and chitinolytic enzymes activities in an amphipod gammarid, Gammarus pulex. Firstly, results underline some confounding factors which could bias the interpretation of the effects of PBDEs exposure. We demonstrated that females have bioaccumulated more PBDEs than males, and that the activities of the chitobiase and chitinolytic enzymes were more impacted by the BDE-47 exposure than BDE99. Hence, it appeared that BDE-47 seems to be more toxic than BDE-99, particularly at the highest concentration of exposure $\left(1 \mu \mathrm{g} . \mathrm{L}^{-1}\right)$. Thought the disturbance of chitobiase and chitinolytic enzymes activities observed in this study, PBDEs could affect the moult cycle of $G$. pulex, probably by affecting the hormonal system linked to the moult. Therefore, PBDEs appear as endocrine disruptors for gammarids, as there was previously observed by Wollenberger et al. (2005) on copepod. As in Gammaridae species, the reproduction and juvenile's release in environment are linked to the moult cycle, PBDE exposures could ultimately affect gammarids population, and therefore the freshwater ecosystem functioning. However, further work is needed to understand more accurately the impact of these emergent xenobiotics on the reproductive metabolism of Gammarus pulex.

\section{Acknowledgements}

This work was funded by a grant from the University of Liège (Belgium) in the context of post-doctoral fellowship obtained by Eric Gismondi. We are grateful to Célia Joaquim-Justo for approving the English text.

\section{References}

Alaee, M., Arias, P., Sjödin, A., Bergman, Å., 2003. An overview of commercially used brominated flame retardants, their applications, their use patterns in different countries/regions and possible modes of release. Environ. Int. 29, 683-689.

Baršienè, J., Šyvokiené, J., Bjornstad, A., 2006. Induction of micronuclei and other nuclear abnormalities in mussels exposed to bisphenol $\mathrm{A}$, diallyl phthalate and tetrabromodiphenyl ether-47. Aquat. Toxicol. 78, S105-S108.

Bradford, M.M., 1976. A rapid and sensitive method for the quantification of microgram quantities of protein utilizing the principle of protein-dye binding. Anal. Biochem. 72, 248-254.

Breitholtz, M., Wollenberger, L., 2003. Effects of three PBDEs on development, reproduction and population growth rate of the harpacticoid copepod Nitocra spinipes. Aquat. Toxicol. 64, 85-96.

Christensen, J.H., Glasius, M., Pécseli, M., Platz, J., Pritzl, G., 2002. Polybrominated diphenyl ethers (PBDEs) in marine fish and blue mussels from southern Greenland. Chemosphere 47, 631-638. 
Ciparis, S., Hale, R.C., 2009. Bioavailability of polybrominated diphenyl ether flame retardants in biosolids and spiked sediment to the aquatic oligochaete, Lumbriculus variegatus. Environ. Toxicol. Chem. 24, 916-925.

Coquery, M., Morin, A., Bécue, A., Lepot, B., 2005. Priority substances of the European Water Framework Directive: analytical challenges in monitoring water quality. Trends Anal. Chem. 24, 117-127.

Darnerud, P.O., Eriksen, G.S., Jóhannesson, T., Larsen, P.B., Viluksela, M., 2001. Polybrominated diphenyl ethers: occurrence, dietary exposure, and toxicology. Environ. Health Perspect. 109, 49-68.

Davies, R., Zou, E., 2012. Polybrominated diphenyl ethers disrupt molting in neonatal Daphnia magna. Ecotoxicology 21, 1371-1380.

de Wit, C.A., Herzke, D., Vorkamp, K., 2010. Brominated flame retardants in the Arctic environment - trends and new candidates. Sci. Total Environ. 408, 2885-2888.

European Union, 2001. Diphenyl Ether, Pentabromo Derivative (Pentabromodiphenylether). European Union risk assessment Report. Office for Official Publications of the European Committees, Luxembourg, pp. 1-124.

Gismondi, E., Beisel, J.N., Cossu-Leguille, C., 2012a. Polymorphus Minutus affects Antitoxic responses of gammarus roeseli exposed to cadmium. PLoS One 7, e41475.

Gismondi, E., Beisel, J.N., Cossu-Leguille, C., 2012b. Influence of gender and season on reduced glutathione concentration and energy reserves of Gammarus roeseli. Environ. Res. 118, 47-52.

Gismondi, E., Cossu-Leguille, C., Beisel, J.N., 2013. Do males and females gammarids defend themselves differently during chemical stress? Aquat. Toxicol. 140-141, $432-438$.

Gustafsson, K., Björk, M., Burreau, S., Gilek, M., 1999. Bioaccumulation kinetics of brominated flame retardants (Polybrominated diphenyl ethers) in blue mussels (Mytilus Edulis). Environ. Toxicol. Chem. 18, 1218-1224.

Hanson, M.L., Lagadic, L., 2005. Chitobiase activity as an indicator of aquatic ecosystem health. Aquat. Ecosyst. Health Manag. 8, 441-450.

Hyne, R.V., 2011. Review of the reproductive biology of amphipods and their endocrine Regulation: Identification of mechanistic pathways for reproductive toxicants. Environ. Toxicol. Chem. 30, 2647-2657.

Isosaari, P., Lundebye, A.K., Ritchie, G., Lie, Ø., Kiviranta, H., Vartiainen, T., 2005. Dietary accumulation efficiencies and biotransformation of polybrominated diphenyl ethers in farmed Atlantic salmon (Salmo salar). Food Addit. Contam. 22, 829-837.

Jażdżewski, K., 1980. Range Extensions of some Gammaridean species in European Inland Waters Caused by Human Activity. Crustaceana Supplement, pp. 84-107.

Kunz, P.Y., Kienle, C., Gerhardt, A., 2010. Gammarus spp. in aquatic ecotoxicology and water quality assessment: toward integrated multilevel tests. In: Whitacre, D.M. (Ed.), Reviews of Environmental Contamination and Toxicology. Springer New York, New York, pp. 1-76.

La Guardia, M.J., Hale, R.C., Harvey, E., 2006. Detailed polybrominated dipheny ether (PBDE) congener composition of the widely used Penta-, Octa-, and DecaPBDE technical flame-retardant mixtures. Environ. Sci. Technol. 40, 6247-6254.

Lema, S.C., Schultz, I.R., Scholz, N.L., Incardona, J.P., Swanson, P., 2007. Neural defects and cardiac arrhythmia in fish larvae following embryonic exposure to $2,2^{\prime}, 4,4^{\prime}$ tetrabromodiphenyl ether (PBDE 47). Aquat. Toxicol. 82, 296-307.

Lema, S.C., Dickey, J.T., Schultz, I.R., Swanson, P., 2008. Dietary exposure to 2,2',4,4' tetrabromodiphenyl ether (PBDE-47) alters thyroid status and thyroid hormone-regulated gene transcription in the pituitary and brain. Environ. Health Perspect. 116, 1694-1699.

Leroy, D., Haubruge, E., De Pauw, E., Thomé, J.P., Francis, F., 2010. Development of ecotoxicoproteomics on the freshwater amphipod Gammarus pulex: identification of PCB biomarkers in glycolysis and glutamate pathways. Ecotoxicol. Environ. Saf. 73, 343-352.

Mhadhbi, L., Fumega, J., Boumaiza, M., Beiras, R., 2012. Acute toxicity of polybrominated diphenyl ethers (PBDEs) for turbot (Psetta maxima) early life stages (ELS). Environ. Sci. Pollut. Res. 19, 708-717.

Muirhead, E.K., Skillman, A.D., Hook, S.E., Schultz, I.R., 2006. Oral exposure of PBDE47 in fish: toxicokinetics and reproductive effects in Japanese Medaka (Oryzias latipes) and Fathead Minnows (Pimephales promelas). Environ. Sci. Technol. 40, $523-528$.
Noyes, P.D., Kelly, S.M., Mitchelmore, C.L., Stapleton, H.M., 2010. Characterizing the in vitro hepatic biotransformation of the flame retardant BDE 99 by common carp. Aquat. Toxicol. 97, 142-150.

Parolini, M., Binelli, A., 2012. Cyto-genotoxic effects induced by three brominated diphenyl ether congeners on the freshwater mussel Dreissena polymorpha. Ecotoxicol. Environ. Saf. 79, 247-255.

Richards, S., Kelly, S., Hanson, M., 2008. Zooplankton chitobiase activity as an endpoint of pharmaceutical effect. Arch. Environ. Contam. Toxicol. 54, 637-644.

Sornom, P., Felten, V., Médoc, V., Sroda, S., Rousselle, P., Beisel, J.N., 2010. Effect of gender on physiological and behavioural responses of Gammarus roeseli (Crustacea Amphipoda) to salinity and temperature. Environ. Pollut. 158, 1288-1295.

Sornom, P., Gismondi, E., Vellinger, C., Devin, S., Férard, J.F., Beisel, J.N., 2012. Effects of sublethal cadmium exposure on antipredator behavioural and antitoxic responses in the invasive amphipod Dikerogammarus villosus. PLoS One 7, e42435.

Sutcliffe, D.W., 1992. Reproduction in Gammarus (Crustacea, Amphipoda): basic processes. Freshw. Forum 2, 102-128.

Thomé, J.P., Leroy, D., 2012. Contribution à la mise en place de la Directive Cadre sur l'Eau en Région Wallonne: Evaluation du niveau de contamination par les micropolluants des macroinvertébrés et des poissons dans les rivières wallonnes. Service Public de Wallonie. Direction Générale Opérationnelle "Agriculture, Ressources Naturelles et Environnement", p. 118.

Tlili, K., Labadie, P., Bourges, C., Desportes, A., Chevreuil, M., 2012. Bioaccumulation of polybrominated diphenyl ethers by the freshwater benthic amphipod Gammarus pulex. Arch. Environ. Contam. Toxicol. 63, 69-76.

Tomy, G.T., Palace, V.P., Halldorson, T., Braekevelt, E., Danell, R., Wautier, K., Evans, B., Brinkworth, L., Fisk, A.T., 2004. Bioaccumulation, biotransformation, and biochemical effects of brominated diphenyl ethers in juvenile Lake Trout (Salvelinus namaycush). Environ. Sci. Technol. 38, 1496-1504.

Vellinger, C., Parant, M., Rousselle, P., Immel, F., Wagner, P., Usseglio-Polatera, P., 2012. Comparison of arsenate and cadmium toxicity in a freshwater amphipod (Gammarus pulex). Environ. Pollut. 160, 66-73.

Viganò, L., Roscioli, C., Erratico, C., Guzzella, L., Farkas, A., 2009. Polybrominated diphenyl ethers (PBDEs) in Gammarids, Caddisflies, and Bed Sediments of the Lowland river Po. Bull. Environ. Contam. Toxicol. 82, 200-205.

Waddy, S.L., Burridge, L.E., Hamilton, M.N., Mercer, S.M., Aiken, D.E., Haya, K., 2002. Emamectin benzoate induces molting in American lobster, Homarus americanus. Can. J. Fish. Aquat. Sci. 59, 1096-1099.

Waszak, I., Dabrowska, H., Góra, A., 2012. Bioaccumulation of polybrominated diphenyl ethers (PBDEs) in flounder (Platichthys flesus) in the southern Baltic Sea. Mar. Environ. Res. 79, 132-141.

Weis, J.S., Mantel, L.H., 1976. DDT as an accelerator of limb regeneration and molting in fiddler crabs. Estuar. Coast. Mar. Sci. 4, 461-466.

Wollenberger, L., Dinan, L., Breitholtz, M., 2005. Brominated flame retardants: activities in a crustacean development test and in an ecdysteroid screening assay. Environ. Toxicol. Chem. 24, 400-407.

Wu, J.P., Luo, X.J., Zhang, Y., Luo, Y., Chen, S.J., Mai, B.X., Yang, Z.Y., 2008. Bioaccumulation of polybrominated diphenyl ethers (PBDEs) and polychlorinated biphenyls (PCBs) in wild aquatic species from an electronic waste (e-waste) recycling site in South China. Environ. Int. 34, 1109-1113.

Zhang, H., Pan, L., Zhang, L., 2012. Molecular cloning and characterization of estrogen receptor gene in the Scallop Chlamys farreri: expression profiles in response to endocrine disrupting chemicals. Comp. Biochem. Physiol. C-Pharmacol. Toxicol. Endocrinol. 156, 51-57.

Zou, E., 2005. Impacts of xenobiotics on crustacean molting: the invisible endocrine disruption. Integr. Comp. Biol. 45, 33-38.

Zou, E., Fingerman, M., 1999a. Effects of exposure to diethyl phthalate, 4-(tert)octylphenol, and 2, 4, 5-trichlorobiphenyl on activity of chitobiase in the epidermis and hepatopancreas of the fiddler crab, Uca pugilator. Comp. Biochem. Physiol. C-Pharmacol. Toxicol. Endocrinol. 122, 115-120.

Zou, E., Fingerman, M., 1999b. Patterns of N-acetyl- $\beta$-glucosaminidase isoenzymes in the epidermis and hepatopancreas and induction of N-acetyl- $\beta$-glucosaminidase activity by 20-hydroxyecdysone in the fiddler crab, Uca pugilator. Comp. Biochem. Physiol. C-Pharmacol. Toxicol. Endocrinol. 124, 345-349. 